\title{
Neutrophil elastase and cathepsin G protein and messenger RNA expression in bone marrow from a patient with Chediak-Higashi syndrome
}

\author{
D Burnett, C J Ward, R A Stockley, R G Dalton, A J Cant, S Hoare, J Crocker
}

Lung

Immunobiochemical

Research Laboratory,

The General Hospital,

Birmingham

D Burnett

D J Ward

A R Stockley

Department of

Pathology,

Cheltenham General

Hospital

R G Dalton

\section{Children's}

Department,

Newcastle General

Hospital, Newcastle

upon Tyne

A J Cant

$S$ Hoare

Department of

Histopathology,

Birmingham

Heartlands Trust

Hospital

J Crocker

Correspondence to:

Dr D Burnett,

Liver and Hepatobiliary Unit

Research Laboratories,

Clinical Research Block,

Edgbaston, Birmingham B15

$2 \mathrm{TH}$.

Accepted for publication

8 November 1994

\begin{abstract}
Aims-To determine whether neutrophil elastase and cathepsin $G$ are expressed, at transcriptional or translational levels, in the bone marrow from a patient with Chediak-Higashi syndrome.

Methods-Blood neutrophils were isolated from three patients with Chediak-Higashi disease and bone marrow was collected from one. Cell lysates were analysed for neutrophil elastase and cathepsin $G$ activity by enzyme linked immunosorbent assay and western immunoblotting. Northern blotting was used to detect messenger RNA (mRNA) for cathepsin G, elastase and $\beta$-actin in bone marrow extracts, and immunohistochemistry was used to localise the enzymes in marrow myeloid cells.
\end{abstract}

Results-Elastase and cathepsin $G$ were not detected in blood neutrophils from the patients with Chediak-Higashi disease, but were present in bone marrow cells, although immunohistochemistry showed they were not within cytoplasmic granules. The concentrations of elastase and cathepsin $G$ in Chediak-Higashi bone marrow were about 25 and $15 \%$, respectively, of those in normal marrow. Quantitative scanning of northern blots showed that elastase and cathepsin $\mathbf{G}$ mRNA, corrected for $\beta$-actin mRNA, were expressed equally in normal marrow.

Conclusions-Transcription of elastase and cathepsin $\mathbf{G}$ mRNA in promyelocytes of patients with Chediak-Higashi disease is normal, but the protein products are deficient in these cells and absent in mature neutrophils. This suggests that the translated proteins are not packaged into azurophil granules but are degaded or secreted from the cells.

(f Clin Pathol: Mol Pathol 1995;48:M28-M34)

Keywords: Chediak-Higashi syndrome, elastase, cathepsin $\mathrm{G}$.

Chediak-Higashi syndrome is an autosomal recessive disorder characterised by abnormal cytoplasmic granules in a variety of cells. ${ }^{1} \mathrm{~A}$ major sequela of Chediak-Higashi syndrome is recurrent infection, which is thought to result from inefficient microbial killing by leucocytes, despite normal phagocytic activity and a normal respiratory burst. ${ }^{2}$ This defect therefore appears to be associated with a deficiency in killing of bacteria by microbicidal proteins in phago- lysosomes. Blood neutrophils of patients with Chediak-Higashi syndrome are deficient in the azurophil granule enzymes cathepsin $G$ and elastase. Myeloperoxidase and the defensins, however, are present in normal or slightly reduced amounts, ${ }^{34}$ myeloperoxidase having been localised to the granules of the cells. ${ }^{5}$

Cathepsin G and elastase are also deficient in blood neutrophils of the Chediak-Higashi animal model, the beige mouse. ${ }^{6}$ The bone marrow of the beige mouse, however, contains about half the elastase and cathepsin G content of normal mouse marrow, within neutrophil precursors but not mature cells. ${ }^{7}$ These results suggest that in this animal model the cathepsin $G$ and elastase genes are transcribed and protein translation does occur, but the enzymes do not survive to the stage of mature cells. It is not known whether a similar situation exists in human Chediak-Higashi disease, or indeed whether transcription of these proteins is normal. The purpose of the present study was to analyse the messenger RNA (mRNA) and protein content of cathepsin $\mathrm{G}$ and elastase in the bone marrow of patients with ChediakHigashi syndrome.

\section{Methods}

Three patients with Chediak-Higashi syndrome were studied. Diagnosis was based on a history of recurrent infection, depigmented areas of skin, hair or retina, and characteristic giant granules in leucocytes. None had evidence of neuropathy.

Patient JF is a 25 year old man who was diagnosed when aged 13 years. He has suffered from recurrent gingivitis, eventually requiring extraction of all his teeth, and multiple skin infections which have been treated with antibiotics and occasional surgical drainage. $\mathrm{He}$ has had no major chest or urinary tract infections.

Patient GH is a 10 year old boy, diagnosed when five years old. He has had a history of frequent respiratory tract and throat infections, oral ulceration, paronychia, and skin bruising following minor trauma. Relatively minor abrasions to the skin were delayed in healing and often became septic.

Patient $\mathrm{AE}$ is a four year old girl with a history of recurrent infections of the urinary tract, respiratory tract and throat from the age of six weeks. She has recently suffered from mouth ulcers and paronychia.

Blood neutrophils were purified as described by Jepsen and Skottun. ${ }^{8}$ Venous blood was collected, from the three patients and from a 
healthy volunteer, into lithium heparin anticoagulant and each blood sample was diluted with an equal volume of $0.15 \mathrm{~mol} / 1 \mathrm{NaCl}$ solution. The diluted blood $(5 \mathrm{ml})$ was layered onto two layers of Percoll (Pharmacia AB, Uppsala, Sweden); the upper layer was $2 \mathrm{ml}$ $1.075 \mathrm{~g} / \mathrm{ml}$ Percoll, the lower $3 \mathrm{ml} 1.096 \mathrm{~g} / \mathrm{ml}$ Percoll. The tubes were centrifuged at $2000 \times g$ for 20 minutes. The neutrophils were harvested from the interface between the Percoll layers, washed three times in TRIS buffered RPMI 1640 medium (Flow Laboratories, Rickmansworth, UK), counted and resuspended in RPMI 1640 medium. The polymorphonuclear leucocytes (PMN) were $>96 \%$ pure and $>98 \%$ viable (assessed by exclusion of trypan blue). The neutrophil preparations from each subject were separated into two samples, centrifuged and the cell pellets retained. One sample from each subject (for enzyme activity assays) was lysed by the addition of $0.5 \mathrm{M}$ Tris/ $\mathrm{HCl}, \mathrm{pH}$ $7 \cdot 8$, containing $1 \cdot 0 \mathrm{M} \mathrm{NaCl}$ and $0 \cdot 1 \%(\mathrm{v} / \mathrm{v})$ Triton X-100 and sonicated $(6 \times 20 \mathrm{~W})$ using a Lucas Dawe Ultrasonics Soniprobe. The second sample (for western immunoblotting and enzyme linked immunosorbent assay (ELISA)) was lysed by sonication with $0.5 \mathrm{M}$ Tris $/ \mathrm{HCl}$, pH $7 \cdot 8$ containing $1.0 \mathrm{M} \mathrm{NaCl}$ and $0 \cdot 1 \%(\mathrm{v} / \mathrm{v})$ Triton X-100, after the addition of proteinase inhibitors; $25 \cdot 5 \mu \mathrm{l} 100 \mathrm{mM}$ diisopropyl fluorophosphate dissolved in dimethyl sulphoxide, $0 \cdot 1 \mathrm{ml} 0 \cdot 1 \mathrm{M} 1,10$ phenanthroline in methanol and $0.1 \mathrm{ml} 0 \cdot 1 \mathrm{M}$ iodoacetic acid in water. The neutrophil lysates were stored at $-70^{\circ} \mathrm{C}$ until analysed.

Bone marrow $(5 \mathrm{ml}$ ) was aspirated from the superior iliac spine of one of the patients (JF) after obtaining informed consent. After removal of a sample for routine haematological analysis, the remainder was dispensed into $30 \mathrm{ml}$ RPMI 1640 culture medium, containing $10 \%(\mathrm{v} / \mathrm{v})$ fetal calf serum and 2000 units of heparin anticoagulant. A portion of bone marrow was also retained from a haematologically normal bone marrow donor. The marrow samples were centrifuged at $200 \times g$ for 20 minutes through $5 \mathrm{ml} 1.096 \mathrm{~g} / \mathrm{ml}$ Percoll to remove erythrocytes and erythroid precursors. The cells remaining above the Percoll layer were collected, washed in RPMI 1640 medium and cytospin preparations made for differential cell counts and immunohistochemistry. The remainder of the cells were counted and lysates were obtained for western blotting and enzyme assays as for blood neutrophils. Preparations of mRNA were also obtained from bone marrow for northern blotting. The mRNA was prepared from the bone marrow using a Promega PolyATract System 1000 kit (Promega, Southampton, UK) and finally solubilised and stored as described by Chomczynski. ${ }^{9}$

Three complementary DNA (cDNA) probes were used. The elastase probe ${ }^{10}$ was a 516 base pair partial cDNA (supplied by Dr G Salvesen, University of Georgia, Athens, USA) subcloned into the EcoR1 site of pBluescript $\mathrm{KS}(+/-)$. The cathepsin $\mathrm{G} \mathrm{cDNA}^{11}$ (supplied by Dr T Ley, Jewish Hospital, St Louis, USA) was 1.0 kilobase subcloned into the $E c o R 1$ site of Bluescript. A $\beta$-actin probe ${ }^{12}$ (also supplied by $\operatorname{Dr} T$ Ley) was a 1.9 kilobase cDNA in the BamH1 site of Puc9.

Northern blotting was performed essentially as described by Maniatis et al. ${ }^{13}$ The mRNA preparations (about $10 \mu \mathrm{g}$ ) from normal and Chediak-Higashi bone marrow samples, suspended in denaturing buffer (MOPS containing formamide and formaldehyde), were subjected to electrophoresis in $1 \%(\mathrm{w} / \mathrm{v})$ agarose gels in $0.2 \mathrm{M}$ MOPS buffer ( $\mathrm{pH} 7.0$ ) containing $2 \cdot 2 \mathrm{M}$ formaldehyde, $50 \mathrm{mM}$ sodium acetate and $1 \mathrm{mM}$ EDTA. Following electrophoresis, the RNA samples were transferred by capillary blotting to Genescreen TM (NEN Research, Boston, USA). The Genescreen was prehybridised for 12 hours at $42^{\circ} \mathrm{C}$ before the addition of the cathepsin $\mathrm{G}$ probe or the elastase probe $\left(100^{\circ} \mathrm{ng}\right)$, radiolabelled with $\left[{ }^{32} \mathrm{P}\right] \mathrm{dCTP}$ to $10^{9} \mathrm{dpm} / \mathrm{mg}$ DNA using a commercial random prime labelling kit (Boehringer Mannheim, Lewes, UK). Hybridisation took place for 18 hours at $42^{\circ} \mathrm{C}$ in the presence of $50 \%$ formamide. The screens were then washed four times with $2 \times$ standard sodium citrate (SSC) at $20^{\circ} \mathrm{C}$ and twice with $0.2 \times$ SSC at $65^{\circ} \mathrm{C}$ $(1 \times \mathrm{SSC}=0.15 \mathrm{M} \mathrm{NaCl}, 0.015 \mathrm{M}$ sodium citrate, $\mathrm{pH} 7 \cdot 0$ ). The screens were autoradiographed at $-70^{\circ} \mathrm{C}$ and that which had been probed with the elastase cDNA was scanned with LKB Wallach $1205 \beta$ plate flat bed counter in the scintillation mode. When the radioactivity of the elastase probed screen had decayed to undetectable levels, it was reprobed with radiolabelled $\beta$-actin cDNA, autoradiographed and scanned again. The ratios of radioactivity caused by hybridisation of elastase mRNA and $\beta$-actin mRNA in normal and Chediak-Higashi bone marrow samples were calculated from the scans.

Neutrophil and bone marrow lysates were subjected to sodium dodecyl sulphate polyacrylamide gel electrophoresis (SDS-PAGE), as described by Laemmli, ${ }^{14}$ on an LKB "Midget" system (Pharmacia LKB Biotechnology, Milton Keynes, UK) using a 5\% polyacrylamide stacking gel and $12 \cdot 5 \%$ running gel. Each sample loaded contained lysate from $10^{4}$ cells. Following electrophoresis, the proteins were transferred to nitrocellulose paper (Hybond-C; Amersham International) by electroblotting. The nitrocellulose sheets were incubated with either sheep antineutrophil elastase ${ }^{15}$ or sheep anticathepsin $G,{ }^{16}$ followed by donkey antisheep IgG labelled with horseradish peroxidase (Binding Site, Birmingham, UK). Binding of peroxidase labelled antibody was visualised using 3-amino-9-ethylcarbazole as the substrate.

Cathepsin G was measured in blood neutrophil and bone marrow lysates using a direct capture ELISA. Nunc Immuno 96 well plates were loaded with $0.2 \mathrm{ml}$ sheep antihuman cathepsin G, $20 \mu \mathrm{l} / \mathrm{ml}$ in phosphate buffered saline (PBS) ( $\mathrm{pH} \mathrm{7 \cdot 2)}$ and incubated overnight at $4^{\circ} \mathrm{C}$. The wells were washed three times with washing buffer (PBS containing $0 \cdot 1 \%$ Tween20 and $1 \%(v / v)$ Haemaccel (Hoechst)) before the addition of $0.2 \mathrm{ml}$ of each cell lysate diluted in washing buffer with $0.5 \mathrm{M} \mathrm{NaCl}$. Reference 
standards consisted of dilutions of cathepsin $\mathrm{G}$, purified from an empyema as described by Martodam et al. ${ }^{17}$ The plates were incubated for two hours at room temperature before washing, followed by the addition of a horseradish peroxidase conjugated sheep anticathepsin G. After a further two hours of incubation, the wells were washed and substrate added; $0.2 \mathrm{ml} /$ well $1 \mathrm{mg} / \mathrm{ml}$ o-phenylenediamine dihydrochloride (Sigma) in $0.1 \mathrm{M}$ citrate/phosphate buffer ( $\mathrm{pH}$ $5 \cdot 0$ ) with $1 \mu \mathrm{l} / \mathrm{ml}$ hydrogen peroxide. The colour reaction was stopped with $50 \mu \mathrm{l} 0.5 \mathrm{M}$ citric acid/well and the absorbance measured with a Dynatech MR 5000 plate reader at $490 \mathrm{~nm}$. Cathepsin $\mathrm{G}$ concentrations in the cell lysates were calculated by interpolation from the reference values obtained with pure enzyme. The lower limit of detection was $3 \mathrm{ng} / \mathrm{ml}$.

Neutrophil elastase in cell lysates was measured using an indirect competition ELISA. Nunc Immuno 96 well plates were loaded with $0.2 \mathrm{ml}$ elastase, $1 \mu \mathrm{g} / \mathrm{ml}$ in PBS, $\mathrm{pH} 7 \cdot 2$, with $0.5 \mathrm{M} \mathrm{NaCl}$ and incubated overnight at $4^{\circ} \mathrm{C}$. The cell lysates and dilutions of elastase, purified from an empyema, ${ }^{17}$ were each mixed with equal volumes of $25 \mu \mathrm{g} / \mathrm{ml}$ sheep antielastase, which were also incubated overnight at $4^{\circ} \mathrm{C}$. The ELISA plates were washed and the lysates and reference mixtures $(0.2 \mathrm{ml} /$ well $)$ added and incubated for two hours at room temperature. After further washing, the plate wells were loaded with $0.2 \mathrm{ml}$ horseradish peroxidase conjugated donkey antisheep IgG (Binding Site) and incubated for two hours at room temperature, before the addition of substrate solution and measurement of the absorbance at $490 \mathrm{~nm}$, as described earlier. The elastase con- centrations in the cell lysates were calculated by interpolation from the inhibition binding reference line obtained with pure elastase, the lower limit of detection being $3 \mathrm{ng} / \mathrm{ml}$. Results for both enzymes were expressed as pg protein/ myeloid cell.

Cathepsin G and elastase activities in blood neutrophil and bone marrow lysates were measured in microtitre plate wells using fluorimetric substrates, Succ-Ala-Ala-Pro-Phe-paranitroanilide and Succ-Ala-Ala-Ala-paranitroanilide, respectively (Bachem Feinchemikalien, Bubendorf, Switzerland). Samples $(40 \mu \mathrm{l})$ of the cell lystates and dilutions of calibration standards of pure cathepsin $\mathrm{G}$ or elastase were mixed with $140 \mu \mathrm{l}$ substrate buffer $(0.05 \mathrm{~mol} / 1 \mathrm{TRIS} /$ $\mathrm{HCl}$ buffer containing $0.5 \mathrm{~mol} / 1 \mathrm{NaCl}$ and $1 \%$ (v/v) Triton X-100 and $1 \mathrm{mg} / \mathrm{ml}$ of the appropriate substrate). The plates were incubated at room temperature until colour change was sufficient and the absorbance of each well was measured at $410 \mathrm{~nm}$ with a Dynatech MR 5000 plate reader. Cathepsin G and elastase concentrations in cell lysates were calculated by interpolation from the calibration curves obtained with pure enzymes. The lower limits of detection for cathepsin $G$ and elastase activity were 190 and $150 \mathrm{ng} / \mathrm{ml}$, respectively. Results were expressed as activity representing pg enzyme/myeloid cell.

The cytocentrifuge preparations from the bone marrow samples were stained immunohistochemically for cathepsin $\mathrm{G}$ and elastase as described previously. ${ }^{1516 .}$

\section{Results}

NORTHERN BLOTTING

Autoradiographs of northern blots obtained

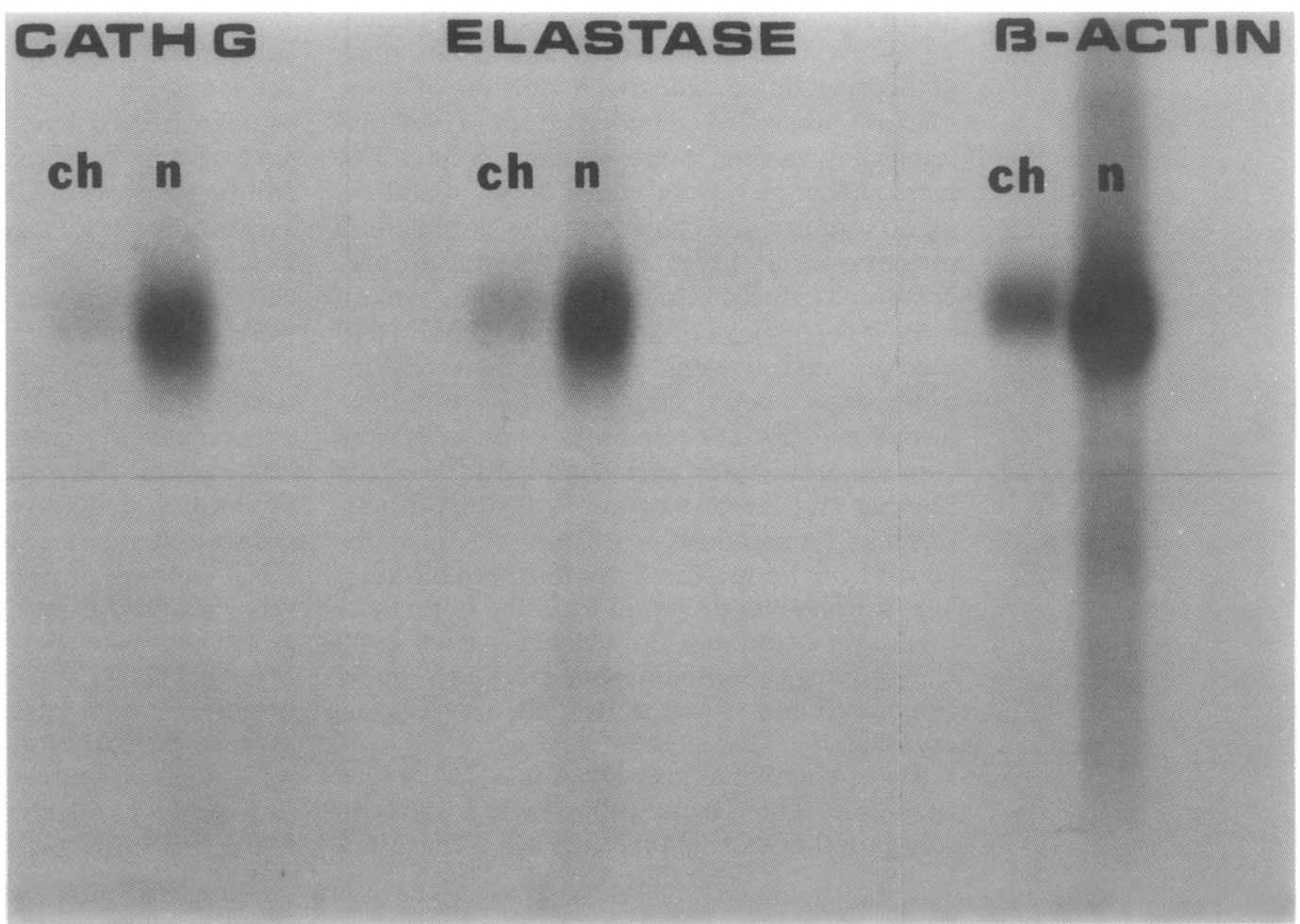

Figure 1 Northern blotting with cDNA probes for cathepsin $G(C A T H G)$, elastase and $\beta$-actin in bone marrow. The figure shows the results of blotting bone marrow myeloid cell $m R N A$ from a normal donor $(n)$ and a patient with Chediak-Higashi disease (ch). The transcripts were of different sizes but the blots are aligned for convenient comparison. 


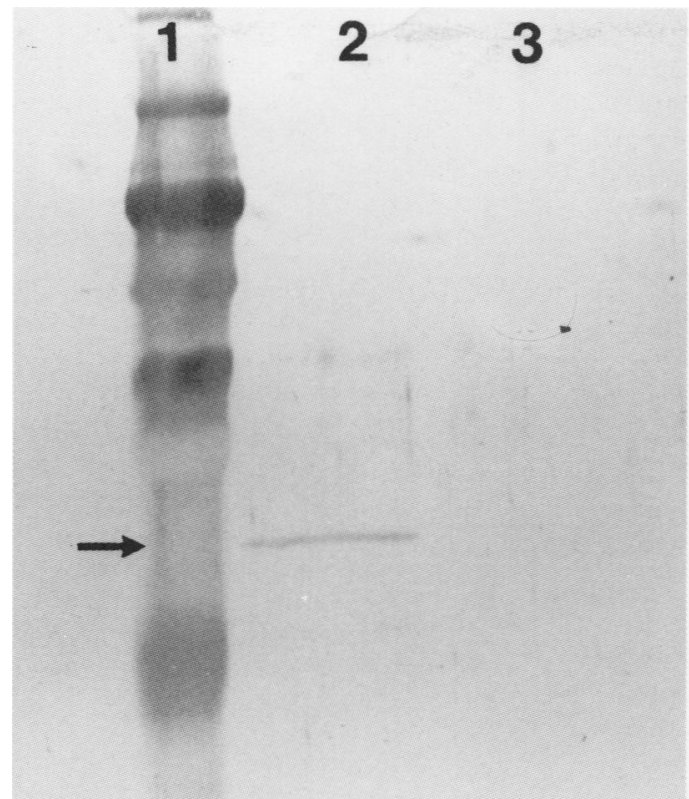

(A)

Figure 2 Western blotting for elastase and cathepsin $G$ in blood neutrophils. The figure shows western blotting for cathepsin $G(A)$ and elastase $(B)$ in blood neutrophil lysates. Lane 1, molecular weight markers; lane 2, neutrophils from the healthy subject; lane 3, neutrophils from a patient with Chediak-Higashi disease. Normal neutrophils contain both enzymes with apparent molecular weights of 29500 (arrows).

with mRNA from normal and Chediak-Higashi bone marrow samples using the elastase, cathepsin $\mathrm{G}$ and $\beta$-actin cDNA probes are shown in fig 1 . Although we attempted to load similar amounts of RNA from normal and ChediakHigashi marrow samples, it is evident, by comparing the intensities of the resulting $\beta$-actin autoradiographs, that the normal marrow samples contained more mRNA. Nevertheless,

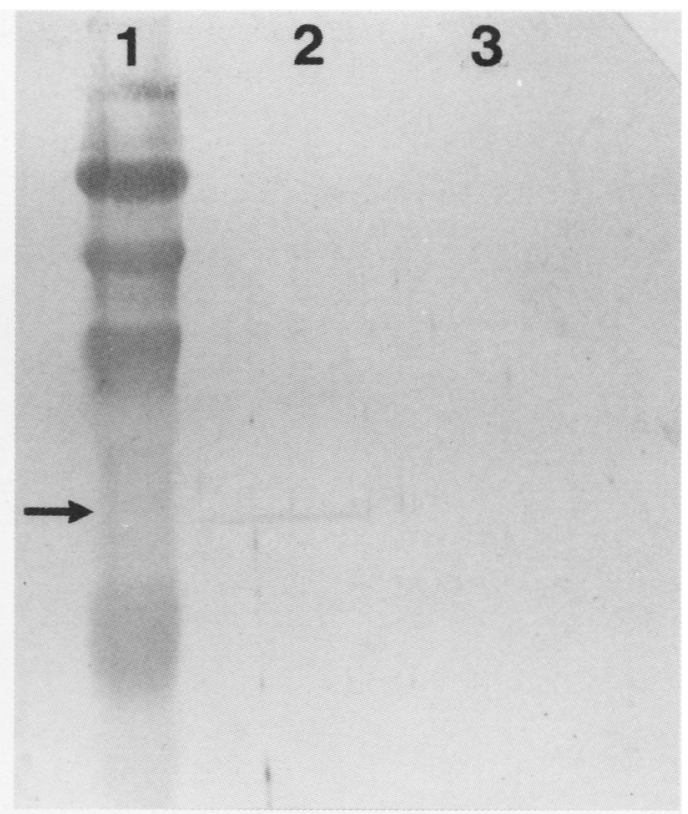

(B) visual comparison of the autoradiographs suggested that the ratios of cathepsin G: $\beta$-actin and elastase: $\beta$-actin were similar in bone marrow samples from both subjects. This was confirmed by the quantitative scanning of the elastase and $\beta$-actin blots. The ratio of elastase: $\beta$-actin transcripts in the normal marrow was 0.34 and that for the Chediak-Higashi marrow was $0 \cdot 40$, suggesting that the two marrow lys-
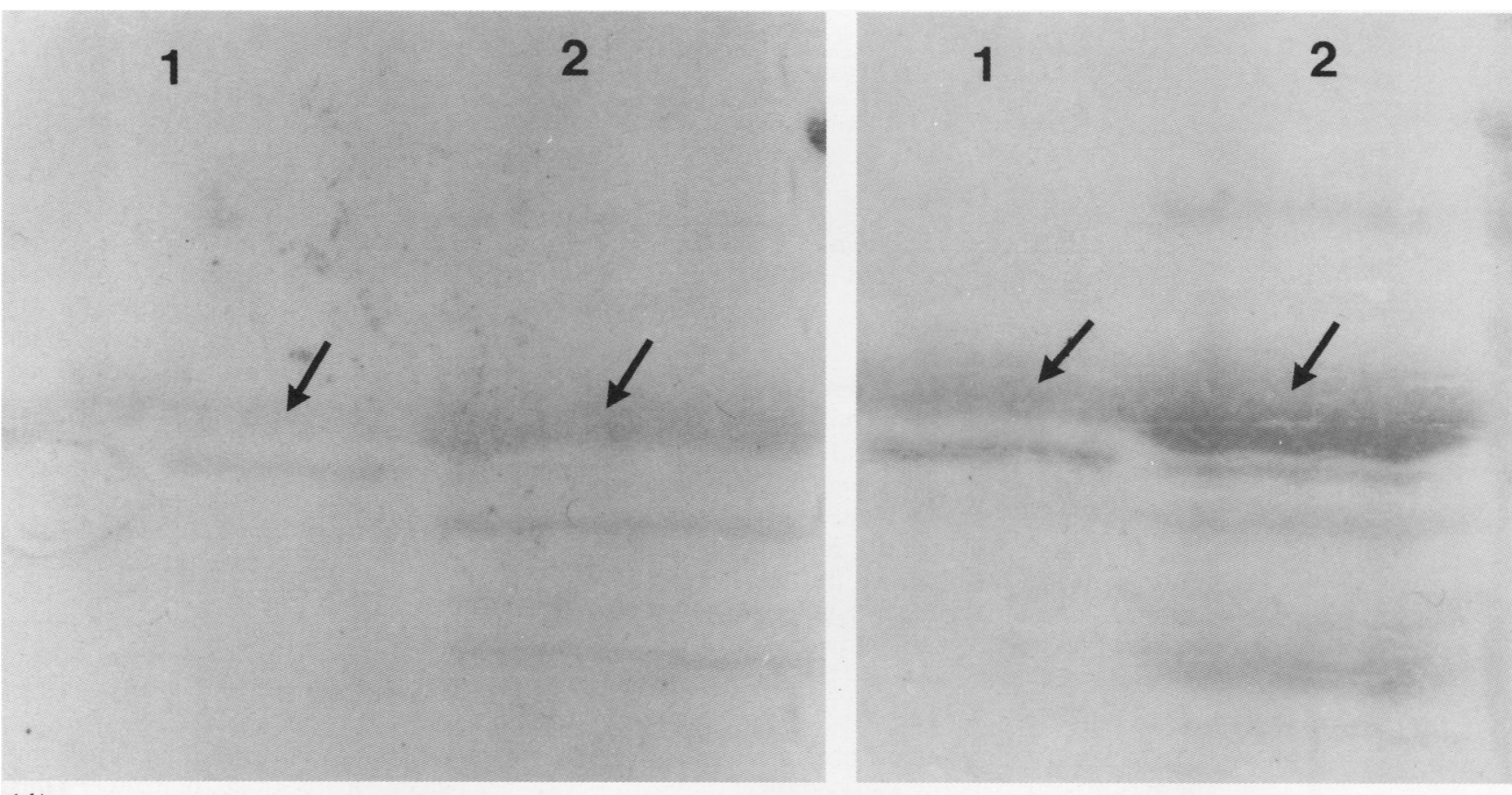

Figure 3 Western blotting of bone marrow. The figure shows western blotting for cathepsin $G(A)$ and elastase (B) in lysates from bone marrow cells. Lane 1, bone marrow from a patient with Chediak-Higashi disease; lane 2, normal marrow. The lysates from normal and Chediak-Higashi bone marrow show cathepsin $G$ and elastase bands of molecular weights consistent with mature active protein (arrows). The Chediak-Higashi marrow lysates also show elastase and cathepsin $G$ bands of smaller sizes. 


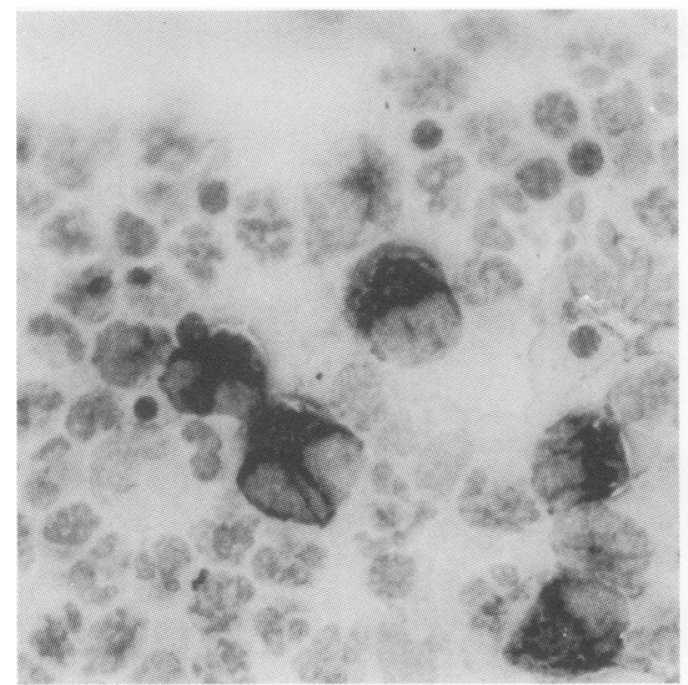

(A)

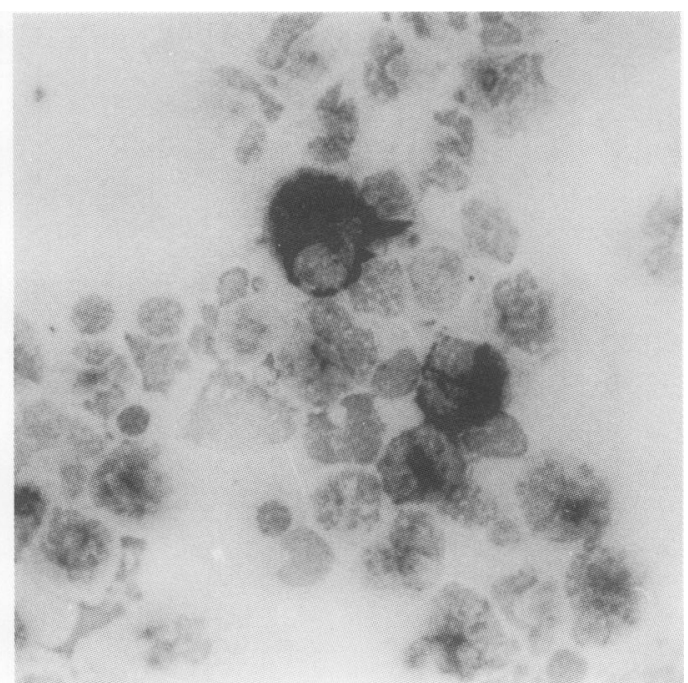

(B)

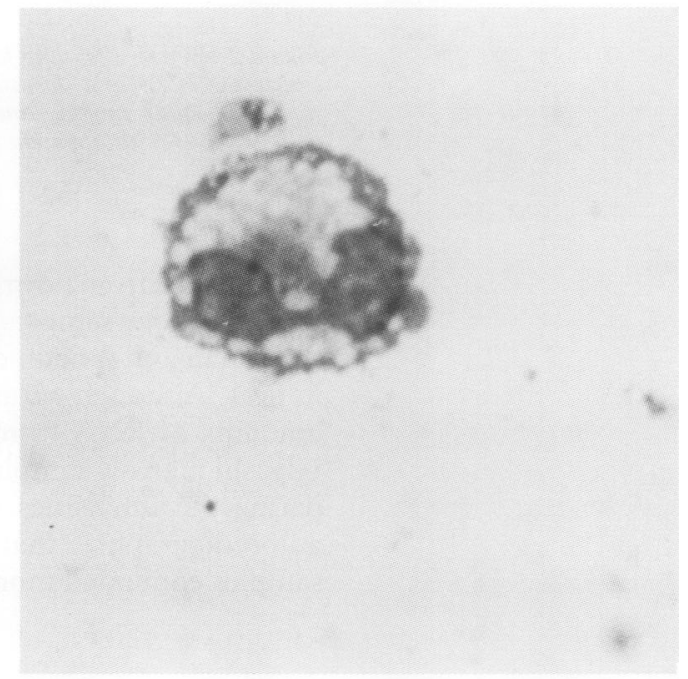

(D)

Figure 4 Immunohistochemical staining of bone marrow promyeloid cells for cathepsin $G$ and elastase. (A) Cathepsin $G$ staining of normal marrow. (B) Elastase staining of normal marrow. (C) Cathepsin $G$ staining of Chediak-Higashi marrow. (D) Elastase staining of Chediak-Higashi marrow. Both enzymes are evident within granules of normal marrow cells, but do not stain within the granules of Chediak-Higashi cells.

ates contained similar amounts of the elastase mRNA transcript relative to that of $\beta$-actin.

\section{WESTERN IMMUNOBLOTTING}

Cathepsin G and elastase were not detected in the lysates from blood neutrophils isolated from any of the three Chediak-Higashi patients, whereas both proteins (molecular weight about 29 500) were evident in the normal neutrophils (fig 2). Figure 3 shows the results of western blotting using lysates from the bone marrow samples. Both normal and Chediak-Higashi marrow lysates contained cathepsin $G$ and elastase protein.

CATHEPSIN G AND ELASTASE CONCENTRATIONS IN BLOOD AND MARROW MYELOCYTES The cathepsin $G$ and elastase concentrations in Chediak-Higashi blood neutrophil lysates, measured using ELISA or enzyme activity, were below the limits of detection of the assays.
Cathepsin G and elastase were detected, using ELISA, in the bone marrow from the Chediak-Higashi patient. Cathepsin G was measured at a concentration of $0.23 \mathrm{pg} /$ myeloid cell, compared with a concentration in normal marrow of $0.97 \mathrm{pg} /$ cell. Elastase was also present in the Chediak-Higashi marrow at a concentration of $0.37 \mathrm{pg} /$ myeloid cell, compared with the normal marrow value of $2.3 \mathrm{pg} /$ cell. Thus, Chediak-Higashi marrow myeloid cells contained 24 and $16 \%$ of the cathepsin G and elastase proteins, respectively, found in the normal marrow. Cathepsin $G$ activity in the marrow cells represented $0.09 \mathrm{pg} / \mathrm{cell}$ in Chediak-Higashi marrow and $0.93 \mathrm{pg} /$ cell in normal marrow. The elastase activity in Chediak-Higashi marrow was $0 \cdot 15 \mathrm{pg} / \mathrm{cell}$ and was $1.2 \mathrm{pg} /$ cell in normal marrow. Thus, cathepsin G and elastase activity in ChediakHigashi marrow cells represented $9 \cdot 8$ and $15 \cdot 8 \%$, respectively, of that in normal marrow cells. 
IMMUNOHISTOCHEMISTRY OF CYTOSPIN PREPARATIONS

Figure 4 shows the results of immunohistochemical staining of bone marrow, from the Chediak-Higashi patient and a normal donor, for cathepsin $G$. In the normal marrow cathepsin $G$ could be seen within the granules of the cells, whereas the Chediak-Higashi promyelocyte granules showed no staining.

\section{Discussion}

In the present study we have confirmed the observation of Ganz et $a l^{4}$ that elastase and cathepsin $G$ are undetectable in mature blood neutrophils from patients with ChediakHigashi disease. The fundamental cause of neutrophil cathepsin $\mathrm{G}$ and elastase deficiency in Chediak-Higashi syndrome has not, however, been established. Elastase, coded for on chromosome 19 pter $^{18}$ and cathepsin G, on chromosome $11 \mathrm{q} 14 \cdot 2,{ }^{11}$ are both transcribed, synthesised and packaged within the promyelocyte during myeloid differentiation in the bone marrow, ${ }^{11} 1920$ when the azurophil granules are formed ${ }^{21}$; transcription and synthesis cease before the cells become mature neutrophils. Both enzymes are translated as pre-pro-proteins and thence processed via enzymatically inactive pro-proteins to the mature active enzymes. ${ }^{22}$ Activation from the pro-enzyme appears to involve the proteolytic removal of an acidic $\mathrm{N}$ terminal dipeptide, Ser-Glu in the case of elastase and Gly-Glu for cathepsin G, and $C$ terminal extensions of 20 and 11 amino acids in elastase and cathepsin $G$, respectively. The $\mathbf{N}$ terminal sequences of the mature proteins share considerable homology, suggesting common dipeptidyl peptidases are responsible for processing the pro-proteins. ${ }^{22}$ The $\mathrm{C}$ terminal extensions of the pro-proteins are not homologous. The mechanisms determining packaging to the azurophil granules are not known. The deficiency of these enzymes in Chediak-Higashi syndrome could potentially occur at any of these several stages of processing. The identification of the mature enzymes within bone marrow promyelocytes of the beige mouse suggested, however, that transcription of the genes for these enzymes and translation of the proteins do occur. Thus, the deficiency would be a consequence of posttranslational events.

In the present study we have shown that in bone marrow from a patient with ChediakHigashi syndrome the levels of the mRNA transcripts for cathepsin $G$ and elastase, when corrected for $\beta$-actin mRNA levels, were similar to those of normal marrow. Thus, if $\beta$-actin transcription is normal in Chediak-Higashi myeloid cells the results would suggest that transcription both of cathepsin $\mathrm{G}$ and elastase is also normal.

The bone marrow myeloid cells of the patients with Chediak-Higashi syndrome contained mature, active elastase and cathepsin G. As in the beige mouse, the concentrations of these enzymes were lower than those of marrow from a normal subject and undetectable in mature blood neutrophils. The Chediak-
Higashi marrow protein concentrations were only about one fifth of those seen in normal marrow. This is less than the value for the beige mouse marrow, which was reported to be about $60 \%$ of normal. ${ }^{6}$

Enzyme activity measurements in marrow samples were slightly lower than the protein concentrations estimated using ELISA. This difference may represent a technical discrepancy. Alternatively, it is possible that some inactive, unprocessed, pro-elastase and procathepsin $\mathrm{G}$ were present within the marrow cells, although there was no evidence for this on the western blots. The western blots of elastase and cathepsin G from ChediakHigashi bone marrow samples showed, in addition to molecular weight bands consistent with the mature proteins, smaller forms which were not observed in lysates of normal marrow or of blood neutrophils. These small forms could represent differences in glycosylation. Alternatively, they might represent proteolysed forms although proteinase inhibitors were added to the marrow and neutrophils before lysis to prevent proteolytic modification of proteins during the processing of samples for blotting. The presence of the "smaller" form of elastase and cathepsin G in Chediak-Higashi marrow suggests, therefore, that some proteolytic degradation may have occurred before sampling - that is, in vivo. This has relevance to the possible fate of these proteins in Chediak-Higashi marrow, but further studies would be necessary to establish the reasons for this observation. Nevertheless, the presence of active elastase and cathepsin $\mathrm{G}$ in the myeloid cells of the Chediak-Higashi marrow shows that these proteins had been synthesised and processed to mature, active enzymes. This indicates that a deficiency in proteinases involved in processing of the pro-enzymes is not responsible for the absence of elastase and cathepsin G in Chediak-Higashi neutrophils.

Takeuchi and Swank $^{23}$ characterised inhibitors of elastase and cathepsin G, which formed covalent complexes with the enzymes, in mature neutrophils of beige mice; these inhibitors were absent from normal mouse cells and beige mouse pro-myelocytes. It was suggested that the absence of elastase and cathepsin $\mathrm{G}$ activities in beige mouse neutrophils was because of the presence of these inhibitors. This would not, however, explain the absence of immunoreactive elastase and cathepsin $\mathrm{G}$ in mature neutrophils, either as native proteins or complexed with putative inhibitors. In addition, the presence of elastase and cathepsin $G$ within marrow myeloid cells, but not apparently within the cells' granules, suggests that these enzymes are absent from mature neutrophils in Chediak-Higashi syndrome because of a failure of transport to, or packaging within, the primary granules of the marrow promyelocytes.

Granule defects are a common feature of several cell types in Chediak-Higashi syndrome, including cells which do not express cathepsin G or elastase. ${ }^{1}$ This suggests that a fundamental defect in granule structure may 
prevent the packaging of some, but not all, neutrophil azurophil proteins. Presumably elastase and cathepsin G, but not myeloperoxidase or the defensins, share common requirements for packaging. Little is known, however, about the mechanisms responsible for intracellular transport of azurophil proteins. It is likely that failure to package cathepsin G or elastase successfully may result in these proteins being degraded intracellularly, resulting in their absence from mature neutrophils, following cessation of synthesis. This would explain the smaller molecular weight forms of these enzymes observed on the western blots from the Chediak-Higashi bone marrow. Should this hypothesis be correct, the detection of cathepsin G and elastase activity within ChediakHigashi marrow cells would suggest that posttranslational processing of these enzymes takes place before the proteins enter the azurophil granules. The site of processing events has, to date, been unclear. ${ }^{22}$

In conclusion, our results suggest that the absence of elastase and cathepsin $G$ in Chediak-Highashi blood neutrophils results from a primary defect in azurophil granule structure which precludes the successful packaging of these enzymes, but permits that of other azurophil granule proteins. Further studies are indicated to identify the fundamental defect in Chediak-Higashi disease and to establish whether failure of phagolysosome formation or the deficiencies of specific granule proteins are responsible for defective bacterial killing by leucocytes in this disease.

Supported by grants from the British Lung Foundation, the Birmingham Hospitals Endowment Fund and the General Hospital Bicentenary Fund.

1 Windorst DB, Pagett GA. The Chediak-Higashi syndrom and the homologous trait in animals. F Invest Dermato 1968;60:529-37.

2 Root RK, Rosenthal AS, Balestra DJ. Abnormal bactericidal, metabolic, and lysosomal functions of Chediak-Higash syndrome leukocytes. 7 Clin Invest 1972;51:649-65.

3 Vassali JD, Piperno-Granelli A, Griscelli C, Reich E. Specific protease deficiency in polymorphonuclear leukocytes of Chediak-Higashi syndrome and beige mice. $\mathcal{f} \operatorname{Exp} M e d$ 1978;147:1285-90.

4 Ganz T, Metcalf JA, Gallin JI, Boxer LA, Lehrer RI. Mi- crobicidal/cytotoxic proteins of neutrophils are deficient in two disorders: Chediak-Higashi syndrome and "specific" granule deficiency. 7 Clin Invest 1988;82:522-6.

5 Gilbert CS, Parmley RT, Rice WG, Kinkade JM. Heterogeneity of peroxidase-positive granules in normal human geneity of peroxidase-positive granules in normal human
and Chediak-Higashi neutrophils. 7 Histochem Cytochem 1993;41:837-49.

6 Takeuchi K, Wood H, Swank RT. Lysosomal elastase and cathepsin $G$ in beige mice. Neutrophils of beige (ChediakHigashi) mice selectively lack lysosomal elastase and cathepsin G. $\mathcal{F} \operatorname{Exp}$ Med 1986;163:665-77.

7 Takeuchi KH, McGarry MP, Swank RT. Elastase and cathepsin $\mathrm{G}$ activities are present in immature bone marrow neutrophils and absent in late marrow and circulating neutrophils of beige (Chediak-Higashi) mice. 7 Exp $M e d$ 1987;166:1362-76.

8 Jepsen LV, Skottun TA. A rapid one-step method for the isolation of human granulocytes from whole blood. Scand 1solation of human granulocytes from
7 Clin Lab Invest $1982 ; 42: 235-8$.

9 Chomczynski P. Solubilization in formamide protects RNA from degradation. Nucleic Acids Res 1992;14:3791-2.

10 Farley D, Salvesen G, Travis J. Molecular cloning of human neutrophil elastase. Biol Chem Hoppe-Seyler 1988;369 (Suppl):3-7.

11 Hohn PA, Popescu NC, Hanson RD, Salvesen G, Ley TJ Genomic organisation and chromosomal localization of the human cathepsin G gene. I Biol Chem 1989;264: 13412-19.

12 Ponte P, Ng S-Y, Engel J, Gunning P, Kedes L. Evolutionary conservation of the untranslated regions of actin mRNAs: DNA sequence of a human beta-actin cDNA. Nucleic DNA sequence of a human
Acids Res 1984;12:1687-96.

13 Maniatis T, Fritsch EF, Sambrook J. Molecular cloning. A laboratory manual. Cold Spring Harbor: Cold Spring Harbor Press, 1982

14 Laemmli UK. Cleavage of structural proteins during the assembly of the head of bacteriophage T4. Nature 1970 227:680-5.

15 Crocker J, Jenkins R, Burnett D. Immunohistochemical demonstration of leucocyte elastase in human tissues. $f$ Clin Pathol 1984;37:1114-18.

16 Crocker J, Jenkins $R$, Burnett D. Immunohistochemical localisation of cathepsin $\mathrm{G}$ in human tissues. Am f Surg Pathol 1985:9.338-43.

17 Martodam RR, Baugh RJ, Twumasi DY, Liener IE. A rapid procedure for the large scale purification of elastase and cathepsin G from human sputum. Prep Biochem 1979;9: $15-3$

18 Zimmer M, Medcalf RL, Fink TM, Mattmann C, Lichter $P$, Jenne DE. Three human elastase-like genes coordinately expressed in the myelomonocyte lineage are organized as a single genetic locus on 19pter. Proc Natl Acad Sci USA 1992;89:8215-19.

19 Heusel JW, Scarpati EM, Jenkins NA, Gilbert DJ, Copeland NG, Shapiro SD, et al. Molecular cloning, chromosomal location and tissue-specific expression of the murine calocation and tissue-specific expression of
thepsin G gene. Blood 1993;81:1614-23.

20 Fouret P, duBois RM, Bernaudin JF, Takahashi H, Ferrans VJ, Crystal RG. Expression of the neutrophil elastase gene during human bone marrow cell differentiation. $f$ Exp Med 1989;160:833-45.

21 Bainton DF, Ullyot JL, Farquhar MG. The developmen of neutrophilic polymorphonuclear leucocytes in human bone marrow: origin and content of azurophil and specific granules. $\mathcal{F}$ Exp Med 1971;134:907-34.

22 Salvesen G, Enghild JJ. An unusual specificity in the activation of neutrophil serine proteinase zymogens. Biochemistry 1990;29:5304-8.

23 Takeuchi KH, Swank RT Inhibitors of elastase and thepsin G in Chediak-Higashi (beige) neutrophils. $f$ Clin Invest 1989;254:7431-6. 